The general absence of drift at a high level on the coast-as, for example, on the top of high coast cliffs-can only be accounted for by its having been denuded previously to the deposition of the fringing terrace of low level clay and drift, and of this there seems good evidence, as the contour of much of the higher drift partakes of the general denudation contour of the older rocks, implying a deposition previous to the excavation of some important river-valleys, and to the existence of the present surface contour.

Benthall Hali, Broseley,

Georgu Maw. April $12 t h, 1867$.

Note.-Since the above was written Mr. Fisher's article "on the Ages of the Trail and Warp" has appeared in the Magazine. As I have had but little opportunity of examining the deposit designated by Mr. Fisher as "Trail," I must defer to his opinion that it is identical with what Mr. Dawkins considered to be a Glacial deposit overlying the Brick-earths of the Thames valley; at the same time if it is a subaërial deposit, arranged by the action of land-ice, it does not seem improbable that it may be the equivalent in time of the coast Boulder-clay.

If I rightly understood Mr. Dawkins' observations in the discussion on his paper, he seemed rather to consider the supposed Glacial deposits of the Thames valley as a submarine than a subaërial formation. Under any view, the facts brought forward by Mr. Fisher seem consistent with a long interval between the deposition of the Boulder-clay on the higher ground of the east of England, and that of the supposed Glacial beds of the Thames valley. As the highlevel Boulder-clay is intersected by the present valley system, whilst Mr. Fisher's "Trail" follows its denudation contour, I believe there is evidence that the Till of the Norfolk coast was also deposited after the Boulder-clay of the high ground had been considerably denuded.

The deposit in the valley of the Yare, described as "a Third Boulder-clay," in Mr. Harmer's paper, just published in No. 90 of the Quarterly Journal, appears to occupy a similar position to that which I believe the coast clay of Cromer, Mundsley, etc., bears in relation to the Chalk, Crag, and High-level Boulder-clay, and may merely be an inland extension of the beds on the coast, deposited after the land surface received its present denudation contour.

Similar beds of Brick-earth to that numbered 5 in Mr. Harmer's section, occur interstratified with the bed of gravel (Mr. Wood's Middle Drift), underlying the Boulder-clay of High Suffolk, and its identification with the coast clay seems to me scarcely supported by sufficient proof.-G.M.

ON THE PARALLELISM OF THE DRIFT DEPOSITS IN LANCASHIRE AND NORFOLK.

To the Editor of the Grological Magazing.

SrR,-Mr. Hull has very faithfully drawn, although in somewhat rough outlines, a parallel between the Drift deposits in Lancashire 
(with which he is so well acquainted) and those in the Eastern Counties. $^{1}$ I do not known whether Mr. Hull has ever visited Norfolk, or whether he has been guided by Mr. Wood's description alone. I have had the privilege of studying the deposits in both districts, and can testify to the surprising parallelism which obtains between them. The differences are even such as we should have expected, à priori, to result from local causes, and, instead of detracting from the general resemblance, rather corroborate the opinion that the deposits in both districts were formed under analogous circumstances.

Mr. Searles Wood's outline of Norfolk Drift is correct. We have the three great divisions of Lower, Middle, and Upper Drift-the last but one consisting of mingled sand and gravel. These are the broad features which distinguish the Drift deposits of the North. The principal distinction between the two is that those of the North are considerably thicker than those in the East. True, the Lower Boulder-clay along the coast attains a great thickness, but it is somewhat singular that it should so rarely be found inland, and then only in bands of a few feet thick. Whether this has resulted from the thinning out or denudation of this deposit in a south-westerly direction or not, I cannot say. The coast Boulder-clay has been formed principally by the wreck and denudation of the Lias, ${ }^{2}$ insomuch that it obtains its blue colour from that circumstance, and literally teems with the re-deposited shells of the Lias, such as Grypheea and Ammonites. Its great thickness along the coast, and its thinning inland, would argue that it formerly extended in the North-east, over what is now the German Ocean. The boulders are of Scandinavian rocks in almost every instance. It is more argillaceous, and consequently resembles its relative in Lancashire much more than the Upper Boulder-clay does. In Lancashire it is largely developed, and is extensively used for making bricks. Its almost entire absence inland in Norfolk, therefore, prohibits any such application.

As regards the Middle Drift in Norfolk, it resembles that in the North more than either of the other two members. Like its northern representative, it is found in alternate layers of gravel and fine or coarse sand, is often false bedded, and the pebbles are much waterworn. These are singularly enough composed of granite, quartz, and trap, as the same bed in Lancashire, and I have even detected portions of the silicious grit known there as the "Gannister rock." The shells found in the Middle Drift of Norfolk complete the resemblance. At Stoke and Saxlingham (within ten miles of Norwich) I have found Turritella communis-a shell which I myself found in a similar position in the Middle Drift sands at Reddish and Hyde, in Lancashire; as well as in the sands at Crewe, in Cheshire. Other shells, many of them fragmentary, were also of similar species in both localities.

The Upper Drift or Boulder-clay of Norfolk differs from that of Lancashire more than any of the other divisions. The boulders of primary rocks are not near so abundant as they are in the North. In fact they are generally Oolitic, or flint nodules little worm down.

i See Geor. MaG. Vol. IV., April, 1867, p. 183. '2 And Kimmeridge Clay ?-EdrT. 
All seem to have come from a less distance than those of Lancashire. Mr. Hull gives the percentage (as determined by Professor Ramsay) of rock fragments found in the Upper Boulder-clay at Gorton, in Lancashire, as follows (vide Geol. of Country around Oldham: Memoirs of Geological Survey):

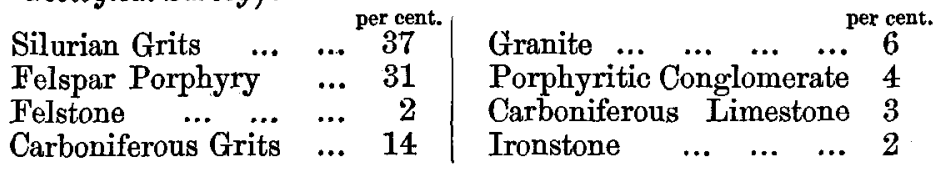

In this case the Silurian Grits, which are most abundant in the Upper Boulder-clay of Lancashire, may be taken to represent their having been conveyed from a distance (the Silurians of Cumberland and north of Lancashire) equivalent to the distance of the source of the Oolitic pebbles found in the Upper Boulder-clay of Norfolk (the Oolite of Yorkshire). The greater percentage of igneous boulders found in the Lancashire Drift beds may arise from the fact of their being nearer to their parent rock than those of the corresponding beds in Norfolk. The small percentage of boulders of local rock (sandstone) in Lancashire, as compared with the much greater percentage of flint boulders in Norfolk, may arise from the different nature of the two parent beds whence both were derived. It would be much easier for marine or glacial agency to disintegrate the Chalk and liberate the enclosed flint nodules, than it would be to break up a sandstone bed and to roll the fragments into boulders. But these exceptions seem to me to carry out the analogy between the northern and eastern deposits instead of detracting from their relation.

Mr. Binney very justly remarks ${ }^{l}$ on the varying nature of the beds which compose the various members of the Drift or Quaternary formation. The same feature is, more or less, common in Norfolk, although it is not so decidedly shown as in Lancashire, owing to the absence of high hills, along whose base, in the North, the various drift beds usually split up into almost unrecognisable portions. At Sprowston in Norfolk, in the Upper Boulder-clay, there are thin seams of sand intercalated, in which Mr. T. G. Bayfield and myself found numerous fragments of marine shells, among others of Cyprina Islandica and Astarte borealis. But both in Lancashire and in Norfolk these local deposits do not affect the general features of resemblance so broadly manifested in both districts.

$$
\text { I remain, etc., }
$$

NoRwICH, May 8th, 1867.

JOHN E. TAYLOR.

\section{BALA AND HIRNANT LIMESTONES AT MYNYD FRON FRYS IN GLYN CEIRIOG.}

To the Editor of the Grologrosi Magazine.

Dear Str,--i am glad to find Mr. Salter calling attention in this month's Magazine to one of the most interesting spots in North Wales-especially so to students of the Lower Silurian group.

1 See Geol. MaG. Vol. IV., May, 1867, p. 231. 